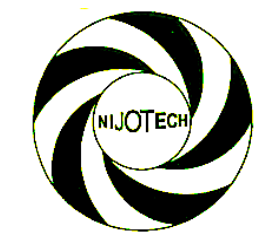

Nigerian Journal of Technology (NIJOTECH)

Vol. 38, No. 4, October 2019, pp.884 - $\mathbf{8 9 5}$

Copyright@ Faculty of Engineering, University of Nigeria, Nsukka,

Print ISSN: 0331-8443, Electronic ISSN: 2467-8821

www.nijotech.com

http://dx.doi.org/10.4314/njt.v38i4.10

\title{
DEVELOPMENT AND VALIDATION OF COMPETENCY-BASED INSTRUMENT FOR ASSESSING MECHANICAL METALWORK TECHNOLOGY OPERATIONS OF TECHNICAL COLLEGES.
}

\author{
P. I. Obe ${ }^{1, *}$, A. O. Ezeama ${ }^{2}$, T. C. Ogbuanya ${ }^{3}$ and E. O. Ede ${ }^{4}$ \\ $\mathbf{1 , 3 , 4}$, DEPT OF INDUSTRIAL TECHNICAL EDUCATION, UNIVERSITY OF NIGERIA, NSUKKA, ENUGU STATE, NIGERIA \\ 2, DEPARTMENT OF MECHATRONIC ENGINEERING, UNIVERSITY OF NigeRIA, NSUKKA, ENUGU STATE, NIGERIA \\ E-mail addresses: ${ }^{1}$ pauline.obe@unn.edu.ng, ${ }^{2}$ osita.ezeama@unn.edu.ng, \\ 3 chinyere.ogbuanya@unn.edu.ng, ${ }^{4}$ emmanuel.ede@unn.edu.ng
}

\section{ABSTRACT}

It is important to develop and validate a competency-based instrument for assessing mechanical metalwork technology students in technical colleges in Enugu and Ebonyi states Nigeria. The study was guided by three specific purposes, three research questions and one null hypotheses that was tested at 0.05 level of significance. The study adopted instrumentation research design. The study was carried out in the Technical Colleges in Enugu and Ebonyi states Nigeria. The population for the study was 134, made up of the year two students of metalwork technology from the six Government approved technical colleges in Enugu and Ebonyi States. The sample size was 80, made up of year two students of metalwork from the three purposive sampled technical colleges in the states. The instrument for data collection were the Competency-based Instrument for Assessing Metalwork Student's cognitive knowledge on machine operations, Competency-based Instrument for Assessing Metalwork Student's psychomotor (manipulative) skills and Competency-based Instrument for Assessing Metalwork Student's Attitude (affective) skills on machine operations. These make up the competency -based instrument for assessing Metalwork students on Machine Operations (CBIAMSMO). The instruments were developed based on the NBTE curriculum for metalwork technology and the reviewed literature. The instruments passed through factor analysis, face, content and construct validations in order to obtain all the relevant items for the study. The data were analyzed using factor analysis, and Analysis of variance (ANOVA) to answer the research questions and the hypothesis respectively. The findings of the study revealed that the competencybased instrument for assessing metalwork students in machine operations in Technical Colleges should involve the test of cognitive (knowledge), manipulative skills (process and product skills) and attitudinal skills (affective) to make the assessment to be valid and reliable. Based on the findings, it was recommended that National Business and Technical Examinations Board (NABTEB) and Metalwork Teachers should include the competency-based assessment instrument in the assessment of metalwork students of Technical Colleges to obtain a valid and reliable assessment for proper acquisition of skills and sustainable employment thereafter.

Keywords: Mechanical, metalwork technology, competency -based assessment.

\section{INTRODUCTION}

Skill acquisition of the technical college students for sustainable living could be obtained through competency-based education. Anthony [1] defined Competency-based Education as an Education that permits students to obtain qualifications by demonstration of skills and knowledge in a required subject area using a series of carefully designed assessments. Clayton [2] explained that Competency is the combination of knowledge and skills a student must have to be able to gain a certificate. Competency-based Education in the context of this

* Corresponding author, tel: +234 - $803-053-7195$ 
study is an Education that allows metal work students to earn qualifications through demonstration of skills and knowledge in their occupational area using a designed assessment.

Assessment can be defined as the process of judging a person, situation or event. Competency-based assessment is defined as an assessment process that measures the performance of students in knowledge, manipulative skills and attitude in a particular occupational area. Ajayi in Fabiyi [6] described competency -based assessment as the evaluation of the individual abilities or character for effective work. Ogwo [8] explained that competency-based assessment is a kind of examination that is characterized by measurement of knowledge, manipulative skills and attitude obtained by the learner. The knowledge is the cognitive aspect, the manipulative is the psychomotor aspect while the attitude is the affective aspect of the assessment. Competency-based assessment therefore is the assessment that measures the performance of metalwork student's skill, knowledge and attitude in metal work technology.

The assessment methods currently used in technical colleges do not involve this process. Evidence from research studies [3-5] indicated that the popular method of assessing metalwork students in technical colleges is basically on cognitive (knowledge) and on product assessment of projects, leaving out the process assessment of the psychomotor competency and the affective competency (attitude). Supporting this, Ayuba [7] stressed that at present the assessment process used by the teachers and NABTEB in technical colleges only helps to determine the performance of the students in cognitive (knowledge).

Technical colleges are the vocational institutions that are responsible for producing craftsmen and master craftsmen in Nigeria. Technical colleges offer vocational education programme for the purpose of producing skilled manpower required for the nation's economic and technological development [9].

Metalwork technology being one of the programs offered in technical colleges involves the process of shaping or producing metal products out of metal. Metalwork technology consists of some occupational areas such as machine work technology, forging/ foundry work, welding work and auto mobile. This study focused on machine work of metalwork technology which according to Chris and John (ND) makes up the largest single occupational cluster (group) in the metal- work technology. It is then imperative that training and assessment in machine work operations in metal work technology should not be left to chance or be done haphazardly. The machine work operations studied in this work are the drilling and milling operations.

Machine work in the context of this study is the art whereby metal work students use machine tool to make metal product like hand tools. Metalwork students according to Ayuba (2007) are meant to achieve adequate skills in machine operation to make them employable. To achieve this at the Technical college level, Students need to be well assessed.

\section{STATEMENT OF THE PROBLEM}

The extent of skill attainment in a competency-based subject like metal work technology is ascertained through a competency-based assessment process. Machine work being one of the occupational areas of metal work technology offered in Technical colleges in Nigeria is designed to equip student with skills necessary for securing paid employment in industries or being self-employed. However, it has been revealed from research studies that graduates of metalwork technology from technical colleges are unable to perform as expected in their occupational trades. This situation could be attributed to various factors which include; wrong method of assessing the skills of the students of metalwork technology. Evidence from research studies also indicated that the assessment process used in assessing metal work Technology in Technical Colleges is not valid. The National Technical Certificate (NTC) and the Advanced National Technical Certificate (ANTC) examination conducted by NABTEB for assessing metalwork technology are mere assessment of knowledge (cognitive) and the finished products (psychomotor) neglecting the process skills (psychomotor) and the whole affective (attitude). This assessment process has made the metalwork graduates lack sufficient skills and yet have good grades in their assessments, resulting to unemployment, unsustainability of employment and non-self-reliance in machine work operation. This study then seeks to develop a competency-based assessment instrument which could be used by metal work Teachers and examination bodies in assessing students of metalwork technology in machine work to help them acquire the competencies needed for employment.

\section{PURPOSE OF THE STUDY}


The general purpose of the study is to develop and validate a competency-based instrument for assessing mechanical metalwork technology operations of technical colleges.

Specifically the study seeks to:

1. determine the cognitive knowledge required of metalwork students in drilling and milling operations.

2. determine the manipulative skills required of metalwork students in drilling and milling operations.

3. determine the affective skills required of metalwork students in drilling and milling operations.

\section{RESEARCH QUESTIONS}

The following research questions were raised to guide the study:

1. What are the cognitive knowledge required of metalwork students in drilling and milling operations?

2. What are the manipulative skills required of metalwork students in drilling and milling operations?

3. What are the affective skills required of metalwork students in drilling and milling operations?

\section{RESEARCH HYPOTHESIS}

The null hypothesis formulated to guide this study was tested at 0.05 level of significance thus:

There is no significant difference between the mean scores of the students of different ability levels on the use of the competency-based assessment instruments on machine operations.

\section{RESEARCH METHODOLOGY.}

The data analysis was carried out using factor analysis and Analysis of variance (ANOVA) to answer the research questions and to test the hypothesis respectively. These are presented in Tables 1- 7.

In decision making, the principal factor loading was based on acceptable factor loading of 0.40 ; such that any item that has its loading lower than 0.40 was not considered required to be included in the instrument. Cohen, et al [10] explained that the content validation of a test can be achieved by subjecting such a test to factor analysis, the factorial analysis would discard the test items with factor loading less than 0.4 as cut-off point at $10 \%$ over lapping variance. The null hypothesis is rejected if the $p$-value is less than or equal to 0.05 ; otherwise it is retained.
Table 1: Outcome of Factor Analysis on required Items of Cognitive Knowledge on drilling operation

\begin{tabular}{lll}
\hline Items & Factor Loading & Remarks \\
\hline C6 & .569 & Required. \\
C7 & .756 & '' \\
C8 & .325 & Not Required \\
C9 & .815 & Required \\
C10 & .728 & '" \\
C11 & -645 & Not Required \\
C12 & .782 & Required \\
C13 & .425 & "' \\
\hline
\end{tabular}

Table 2: Outcome of Factor Analysis on required Items of Congnitive Knowledge on milling operation

\begin{tabular}{lll}
\hline Items & Factor Loading & Remarks \\
\hline C36 & .749 & Required. \\
C37 & .733 & $\prime \prime$ \\
C38 & .915 & $\prime \prime$ \\
C39 & .694 & $\prime \prime$ \\
C40 & .950 & $\prime \prime$ \\
\hline
\end{tabular}

Table 3: Outcome of Factor Analysis on required Manipulative Skills on drilling operation

\begin{tabular}{|c|c|c|}
\hline Task/Item & \multicolumn{2}{|c|}{ Factor Loading Remarks } \\
\hline$\overline{\text { MDT1_1 }}$ & .614 & Required \\
\hline MDT1_2 & .629 & II \\
\hline MDT1_3 & .477 & $"$ \\
\hline MDT2_1 & .616 & " \\
\hline MDT2_2 & .634 & $\prime \prime$ \\
\hline MDT2_3 & .697 & $\prime \prime$ \\
\hline MDT2_4 & .870 & " \\
\hline MDT3_1 & .790 & " \\
\hline MDT3_2 & 696 & " \\
\hline MDT3_3 & .831 & " \\
\hline MDT3_4 & 652 & " \\
\hline MDT3_5 & .557 & $"$ \\
\hline MDT3_6 & 683 & " \\
\hline MDT4_1 & .810 & " \\
\hline MDT4_2 & .847 & 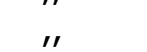 \\
\hline MDT4_3 & .902 & , \\
\hline MDT4_4 & .751 & " \\
\hline MDT4_5 & .568 & , \\
\hline MDT4_6 & .811 & , \\
\hline MDT4_7 & .862 & $\prime \prime$ \\
\hline MDT4_8 & .631 & $\prime \prime$ \\
\hline MDT5_1 & .580 & , \\
\hline MDT5_2 & .650 & $" \prime$ \\
\hline MDT5_3 & .589 & " \\
\hline MDT5_4 & .692 & " \\
\hline MDT5_5 & .683 & " \\
\hline MDT5_6 & .727 & $" \prime$ \\
\hline MDT5_7 & .662 & 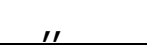 \\
\hline
\end{tabular}

Table 4: Outcome of Factor Analysis on required Manipulative Skills on milling operation 


\begin{tabular}{|c|c|c|}
\hline Task/Item & \multicolumn{2}{|c|}{ Factor Loading Remarks } \\
\hline MMT1_1 & .789 & Required \\
\hline MMT1_2 & .865 & Required \\
\hline MMT1_3 & .750 & " \\
\hline MMT1_4 & .733 & " \\
\hline MMT1_5 & .727 & , \\
\hline MMT2_1 & .833 & " \\
\hline MMT2_2 & .802 & $\prime \prime$ \\
\hline MMT2_3 & 690 & , \\
\hline MMT2_4 & .665 & " \\
\hline MMT2_5 & .718 & , \\
\hline MMT3_1 & .701 & " \\
\hline MMT3_2 & .642 & " \\
\hline MMT3_3 & .487 & " \\
\hline MMT3_4 & .764 & $\prime \prime$ \\
\hline MMT3_5 & .721 & , \\
\hline MMT4_1 & .469 & " \\
\hline MMT4_2 & 696 & " \\
\hline MMT4_3 & .856 & $\prime \prime$ \\
\hline MMT4_4 & .810 & " \\
\hline MMT4_5 & .700 & " \\
\hline MMT5_1 & 683 & $\prime \prime$ \\
\hline MMT5_2 & .462 & .. \\
\hline MMT5_3 & .389 & N R \\
\hline MMT5_4 & .592 & Required \\
\hline MMT5_5 & .644 & , \\
\hline
\end{tabular}

Table 5: Outcome of Factor Analysis on required Items of affective skills on drilling operations

\begin{tabular}{lll} 
Task/Item & Factor Loading & Remarks \\
\hline AD1 & .353 & $\mathrm{~N} \mathrm{R}$ \\
AD2 & .736 & Required \\
AD3 & .805 & '" \\
AD4 & .806 & Required
\end{tabular}

\begin{tabular}{llc} 
Task/Item & Factor Loading & Remarks \\
\hline AD5 & .831 & $\prime \prime$ \\
AD6 & .787 & $\prime \prime$ \\
AD7 & .613 & $\prime \prime$ \\
AD8 & .763 & $\prime \prime$ \\
AD9 & .741 & $"$ \\
AD10 & .712 & $"$ \\
AD11 & .719 & $"$ \\
AD12 & .759 & $"$ \\
AD13 & .616 & $"$ \\
AD14 & .784 & $"$ \\
AD15 & .544 & " \\
AD16 & .722 &
\end{tabular}

Table 6: Outcome of Factor Analysis on required Items of affective skills on milling operations

\begin{tabular}{llc} 
Task/Item & \multicolumn{2}{l}{ Factor Loading Remark } \\
\hline AM1 & .307 & N R \\
AM2 & .789 & Required \\
AM3 & .790 & $\prime \prime$ \\
AM4 & .784 & $\prime \prime$ \\
AM5 & .715 & $\prime \prime$ \\
AM6 & .812 & $\prime \prime$ \\
AM7 & .567 & $\prime \prime$ \\
AM8 & .686 & $\prime \prime$ \\
AM9 & .786 & $\prime \prime$ \\
AM10 & .544 & $\prime \prime$ \\
AM11 & .732 & $\prime \prime$ \\
AM12 & .632 & $\prime \prime$ \\
AM13 & .649 & $\prime \prime$ \\
AM14 & .630 & A \\
AM15 & .790 & .711 \\
AM16 & .711 &
\end{tabular}

Table 7: The ANOVA Analysis on the use of Competency-based Assessment Instrument based on Students

\begin{tabular}{lrrrrr}
\hline \multicolumn{7}{c}{ Ability Levels } \\
\hline Between Groups & Sum of Squares & Df & Mean Square & F & Sig. \\
Within Groups & 14135.002 & 2 & 7067.501 & 403.543 & .000 \\
Total & 1348.548 & 77 & 17.514 & & \\
\hline
\end{tabular}

Table 8: Post Hoc Tests of ANOVA Analysis

\begin{tabular}{|c|c|c|c|c|c|c|}
\hline (I) Ability & (J) Ability & Mean Difference & Std. Error & Sig. & 95\% Confid & ce Interval \\
\hline & & $(\mathrm{I}-\mathrm{J})$ & & & Lower Bound & Upper Bound \\
\hline & AVERAGE & $-25.90657^{*}$ & 1.44175 & .000 & -29.5054 & -22.3078 \\
\hline LOW & $\mathrm{HIGH}$ & $-40.75758^{*}$ & 1.45700 & .000 & -44.3945 & -37.1207 \\
\hline AVFRAGF & LOW & $25.90657^{*}$ & 1.44175 & .000 & 22.3078 & 29.5054 \\
\hline AVLNMUL & $\mathrm{HIGH}$ & $-14.85101^{*}$ & 1.00857 & .000 & -17.3685 & -12.3335 \\
\hline HICH & LOW & $40.75758^{*}$ & 1.45700 & .000 & 37.1207 & 44.3945 \\
\hline HIGH & AVERAGE & $14.85101^{*}$ & 1.00857 & .000 & 12.3335 & 17.3685 \\
\hline The & difference is & at the 0.05 & & & & \\
\hline
\end{tabular}




\section{FINDINGS AND DISCUSSION.}

The data presented in Table 1 shows the outcome of factor analysis on the required items of cognitive knowledge on drilling operation. The table showed that out of eight items constructed to measure the drilling knowledge only one was not required for not having factor loading up to 0.40 while the remaining seven items were required for the development of the instrument.

The data presented in Table 2 indicated that the whole five items constructed to measure the milling operation knowledge were required for the development of the instrument analysis.

The data presented in Table 3 indicated that the whole 28 items raised to measure the manipulative skills in drilling operation were required for the development of the instrument having attain factor value of 0.40 and above.

The data presented in Table 4 indicated that out 25 items raised to assess the manipulative skills in milling operation only one item was not required for the development of the instrument for not having factor value up to 0.4 while the remaining 24 items were required for the development of the instrument for attaining factor value of 0.40 and above.

The data presented in Table 5 indicated that out of 16 item rose to measure the affective skills on drilling operation, only one item was not required for not having factor loading to 0.4 while the remaining 15 items were required for the development of the instrument.

The data presented in table 6 indicated that out of 16 items rose to measure the affective skills on milling operation, only one item was not required for not having factor loading up to 0.4 while the remaining 15 items were required for the development of the instrument.

The data shown in Table 7 reveals that the use of a competency-based assessment instrument is significant based on the students' ability level $p=$ $.000<.05)$. Thus, the null hypothesis is rejected. This implies that there is significant difference between high, average and low ability level students on the use of a competency-based assessment instrument in Machine work operations.

\section{CONCLUSION}

The programme offered in Technical colleges in Nigeria are designed and aimed at providing skills necessary for securing employment in the industry or be self-employed, hence, the products of the metalwork technology at the technical college are expected to be equipped with job skills to enable the individual perform and progress in the chosen trade and in entering into employment. The acquisition of skills in a competency-based learning like metal work technology should be assessed through a competency-based assessment. Competency-based assessment measures the performance of students in skill, knowledge and attitude in a particular occupational area. Insufficient skill acquisition and unemployment nature of metalwork students was by this study attributed to bad assessment instrument used in assessing metalwork student in Technical Colleges in Enugu and Ebonyi states. This situation could be corrected by the use of the developed competency-based assessment instrument to assess metalwork students in machine work operation since it is competency based. It was in the light of these that this study on development and validation of competency-based assessment instrument for assessing mechanical metalwork technology operations was conceived and actualized.

\section{RECOMMENDATIONS}

1. The examination bodies in charge of conducting and organizing examinations for the technical colleges (NABTEB) should integrate the competency-based assessment instrument in their examination for certification of student in metalwork in technical colleges.

2. The NBTE should integrate the developed competency-based assessment instrument into the curriculum of Technical Colleges for training metalwork student.

3. The Nigerian Educational Research and Development council should integrate the Developed competency-based assessment instrument into the vocational curriculum of technical colleges.

4. The competency-based assessment instrument should be used by the teachers in metalwork technology in technical college level to assess the student during teaching and at the final assessment of their student.

\section{REFERENCES}

[1] Anthony W. Competency-based Education: Is this the answer? ; Faculty of adult Education, University of technology,Sydney, NSW,Australia. 2007. 
[2] Clayton C. H. Business school innosight (retrieved from http://: Business school innosight). 2018.

[3] Bukar, F.B. The Basics of Item Response Theory. Retrieved December 14, 2010 from http://www.info.worldbank.org/etools/docs/libr ary/117765/itempercent20 responsepercent2 0theorypercent20percent20fpercent20baker.pdf. 2006.

[4] Chiejile, L. C. Development and validation of a test instrument for assessing students' practical performance in electrical installations. Unpublished doctoral dissertation, Nnamdi Azikiwe University, Awka, Nigeria. 2006.

[5] Okwelle, P.C. Construction of valid evaluation instruments in technology education. Journal of Technical and Science Education. 12 (1\&2) 72 81. 2003.

[6] Fabiyi, S. O. M. Development of CompetencyBased Training Modules in Building Trades for Technical Colleges in Lagos State, South-West of Nigeria. An Unpublished Ph.D Thesis, Department of Industrial Technical Education, University Nigeria, Nsukka. 2016.

[7] Ayuba, Z.G. (2007). Development and Validation of Auditory and Visual Perceptual Test for skills in Machine Tool Technology and Practice. Unpublished Ph.D Thesis, University of Nigeria, Nsukka.

[8] Ogwo, B. A. (2006) Effect of Meta-Learning Instructional Strategy on Students' Achievement in Metal work Technology. Journal of Education Department of Vocational Teacher Education University of Nigeria. Nsukka 17G.

[9] Federal Republic of Nigeria. National policy on education $4^{\text {th }}$ ed. Lagos: NERDC Press.2004.

[10] Cohen, L., Manion, L., Morrison, K., Bell, R., Martin, S., McCcllock, G. \& O `Sullivan, C. (2011) Research Methods in Education 7/e. New York: Routldge Taylor \& Francis

\section{APPENDICES: THE DEVELOPED INSTRUMENT}

\section{APPENDIX A: The developed competency-based assessment instruments for assessing mechanical} metalwork students in drilling and milling operations.

This test is to be given to the metalwork student to answer the questions while the teachers of metalwork technology will mark the scripts with the correct answer options below to determine the student's knowledge of drilling and milling operations.

\section{Choose the correct answer from the option below to answer the following questions:}

1. Drilling is an example of

A. orthogonal cutting

B. oblique cutting

C. simple cutting

D.uniform cutting

2. Twist drills are made of
A. high speed steel
B. carbon steel
C. stainless steel
D.either (a) or (b)

3. A drill considered as a cutting tool having zero rake, is known as a
A. flat drill
B. straight fluted drill
C. parallel shank twist drill
D.tapered shank twist drill

4. If the helix angle of the drill is made $30^{\circ}$, then the torque required to drive the drill at a given feed will be more.

A.equal to

B.less than

C.more than 
5. For softer materials, the point angle of the drill is kept
A. equal to $118^{\circ}$
B. less than $118^{\circ}$
C. more than $118^{\circ}$
D.any one of these

6. High speed steel drills can be operated at about
A. one-half
B. one-fourth
C. Double
D.four times

7. The cutting tool in a milling machine is mounted on
A. Spindle
B. Arbor
C. Column
D.Kne

8. In up milling, the thickness of chip is
A. minimum at the beginning of the cut and maximum at the end of the cut
B. maximum at the beginning of the cut and minimum at the end of the cut
C. uniform throughout the cut
D.none of these
9. Down milling is also called
A. conventional milling
B. climb milling
C. end milling
D.face milling

10. Any number of equal divisions can be obtained on milling machine by
A. direct indexing
B. simple indexing
C. compound indexing
D.differential indexing

\section{Lapping is an operation of}
A. making a cone-shaped enlargement of the end of a hole
B. smoothing and squaring the surface around a hole
C. sizing and finishing a small diameter hole
D.producing a hole by removing metal along the circumference of a hollow cutting tool

\section{APPENDIX B: The competency-based manipulative skills on drilling and milling operations.}

This test is designed to measure the student's ability in performing the manipulative skills in different tasks on drilling and milling operations.

The performance of each manipulative skill on any specific task should be demonstrated by each student and rated by the teacher to express the extent of their performance employing the five point Likert rating scale format with response options in the order of Very high for demonstration of any five (5) skills on the task, High for demonstration of any four (4) skills on the task, Moderately high for demonstration of any three (3) skills on the task, Low for demonstration of any two (2) skills on the task and Very Low for demonstration of any one (1) skill on the task. There will be no mark for none performance of any skill on the tasks. 
Table 8: The competency-based manipulative skills required of metalwork students on Drilling operation.

\begin{tabular}{|c|c|c|c|c|c|c|}
\hline \multirow[b]{2}{*}{$\mathbf{S} / \mathbf{N}$} & \multirow[b]{2}{*}{ Task/ Observable Skills } & \multicolumn{5}{|c|}{ Rating Scales } \\
\hline & & 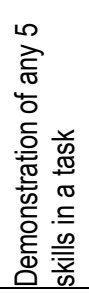 & 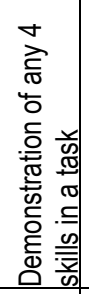 & 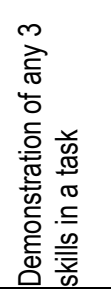 & 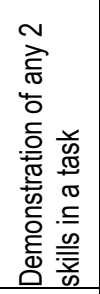 & 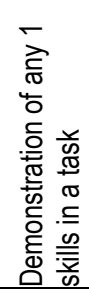 \\
\hline & TASK 1: Centre punching for drill & & & & & \\
\hline 1 & Taking measurement & & & & & \\
\hline 2 & and marking out. & & & & & \\
\hline 3 & Positioning punch. & & & & & \\
\hline 4 & Striking punch head. & & & & & \\
\hline \multirow[t]{3}{*}{5} & Remove and check & & & & & \\
\hline & Task 1 Score & & & & & \\
\hline & TASK 2: Setting up drilling machine. & & & & & \\
\hline 1 & Know the set up height and angle. & & & & & \\
\hline 2 & Set the drilling table to require height and angle. & & & & & \\
\hline 3 & $\begin{array}{l}\text { Hold the work on the drilling table using appropriate clamping } \\
\text { devices. }\end{array}$ & & & & & \\
\hline 4 & Insert the drilling bit in the chuck and tighten & & & & & \\
\hline \multirow[t]{3}{*}{5} & $\begin{array}{l}\text { Lower the spindle and ensure that the drill is in alignment with } \\
\text { the work and drill. }\end{array}$ & & & & & \\
\hline & Task 2 Score & & & & & \\
\hline & TASK 3: Drilling a hole in a metal plate & & & & & \\
\hline 1 & Center punching the point of the hole. & & & & & \\
\hline 2 & Select the correct size and type of the bit for the work. & & & & & \\
\hline 3 & Clamping the work piece. & & & & & \\
\hline 4 & Inserting the drill bit in the chuck. & & & & & \\
\hline 5 & Start the machine & & & & & \\
\hline \multirow[t]{3}{*}{6} & Feed bit on work and drill. & & & & & \\
\hline & Task 3 Score & & & & & \\
\hline & TASK 4: Drill a blind hole in metal bar & & & & & \\
\hline 1 & Start the motor. & & & & & \\
\hline 2 & Gradually press the drill into the work. & & & & & \\
\hline 3 & Change the spindle speed. & & & & & \\
\hline 4 & Drill to a specified depth. & & & & & \\
\hline 5 & Apply coolant at the drilling point. & & & & & \\
\hline 6 & Determine the depth of the hole using stop key. & & & & & \\
\hline 7 & Switch off the machining & & & & & \\
\hline \multirow[t]{3}{*}{8} & Remove the drill from the chuck & & & & & \\
\hline & Task 4 Score & & & & & \\
\hline & TASK 5:Boring in a metal bar & & & & & \\
\hline 1 & Select and fit in the suitable boring bit to the chuck securely & & & & & \\
\hline 2 & $\begin{array}{l}\text { Lower the head stock spindle to the work piece to ensure that } \\
\text { it is centered }\end{array}$ & & & & & \\
\hline 3 & Switch on the machine & & & & & \\
\hline 4 & Bore the work piece to required depth & & & & & \\
\hline 5 & Apply coolant while boring & & & & & \\
\hline 6 & Test with depth guage & & & & & \\
\hline
\end{tabular}




\begin{tabular}{|c|c|c|c|c|c|c|}
\hline \multirow[b]{2}{*}{$\mathbf{S} / \mathbf{N}$} & \multirow[b]{2}{*}{ Task/ Observable Skills } & \multicolumn{5}{|c|}{ Rating Scales } \\
\hline & & 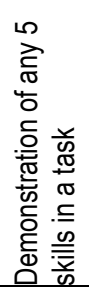 & 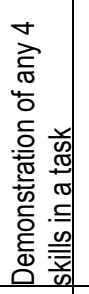 & 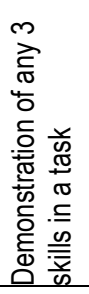 & 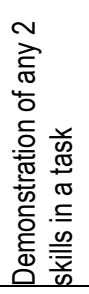 & 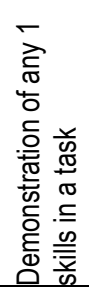 \\
\hline 7 & $\begin{array}{l}\text { Switch off the machine, remove the boring tool from the } \\
\text { chuck. }\end{array}$ & & & & & \\
\hline & Task 5 Score & & & & & \\
\hline
\end{tabular}

Table 9: The competency-based manipulative skills required of metalwork students on Milling operation.

\begin{tabular}{|c|c|c|c|c|c|c|}
\hline \multirow[b]{2}{*}{$\mathbf{S} / \mathbf{N}$} & \multirow[b]{2}{*}{ Task/ Observable Skills } & \multicolumn{5}{|c|}{ Rating Scales } \\
\hline & & 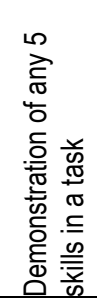 & 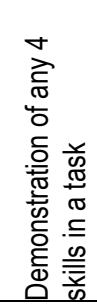 & 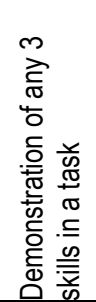 & 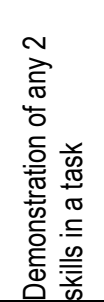 & 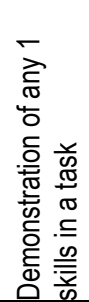 \\
\hline & TASK1: plain peripheral or face milling & & & & & \\
\hline 1 & Setting-up the milling machine & & & & & \\
\hline 2 & Adjustment of vice and clamping the job & & & & & \\
\hline 3 & $\begin{array}{l}\text { Selection of the right tools and switching on the milling } \\
\text { machine }\end{array}$ & & & & & \\
\hline 4 & Performing the plain peripheral or the face milling & & & & & \\
\hline \multirow[t]{3}{*}{5} & $\begin{array}{l}\text { Measure with the correct guage, switching off and } \\
\text { cleaning-up the milling machine }\end{array}$ & & & & & \\
\hline & Task 1 Score & & & & & \\
\hline & TASK 2: angular peripheral & & & & & \\
\hline 1 & Setting-up the milling machine & & & & & \\
\hline 2 & $\begin{array}{l}\text { Adjustment of vice and clamping the work piece on the } \\
\text { milling machine }\end{array}$ & & & & & \\
\hline 3 & Selection of the right tools and switching on the machine & & & & & \\
\hline 4 & Perform the angular peripheral & & & & & \\
\hline \multirow[t]{3}{*}{5} & $\begin{array}{l}\text { Measure with the correct guage, switching off and } \\
\text { cleaning-up the machine }\end{array}$ & & & & & \\
\hline & Task 2 Score & & & & & \\
\hline & TASK 3: milling slots, groves and external keyways & & & & & \\
\hline 1 & Setting-up the milling machine & & & & & \\
\hline 2 & Adjustment of vice and clamping the work piece & & & & & \\
\hline 3 & Selection of the right tools and switching on the machine & & & & & \\
\hline 4 & Perform the slots or the groves job & & & & & \\
\hline \multirow[t]{3}{*}{5} & $\begin{array}{l}\text { Measure with the correct guage, switch off and clean-up } \\
\text { the machine }\end{array}$ & & & & & \\
\hline & Task 3 Score & & & & & \\
\hline & TASK 4: milling of gears & & & & & \\
\hline 1 & Setting-up the milling machine & & & & & \\
\hline 2 & Adjustment of vice and clamping the work piece & & & & & \\
\hline 3 & Selection of the right tools and switching on the machine & & & & & \\
\hline 4 & Milling the gears & & & & & \\
\hline 5 & $\begin{array}{l}\text { Measure with the correct guage, switch off and clean-up } \\
\text { the machine }\end{array}$ & & & & & \\
\hline
\end{tabular}




\begin{tabular}{|c|c|c|c|c|c|c|}
\hline \multirow[b]{2}{*}{$\mathbf{S} / \mathbf{N}$} & \multirow[b]{2}{*}{ Task/ Observable Skills } & \multicolumn{5}{|c|}{ Rating Scales } \\
\hline & & 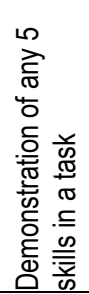 & 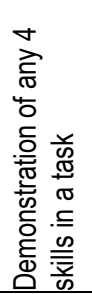 & 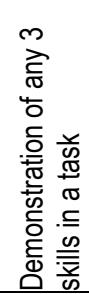 & 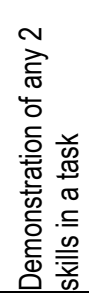 & 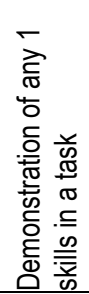 \\
\hline & Score & & & & & \\
\hline & $\begin{array}{l}\text { TASK 5: milling of circular and contour surface } \\
\text { curved }\end{array}$ & & & & & \\
\hline 1 & Setting-up the milling machine & & & & & \\
\hline 2 & Adjustment of vice and clamping the work piece & & & & & \\
\hline 3 & Milling the circular surface curve & & & & & \\
\hline 4 & Measure with the correct guage & & & & & \\
\hline 5 & switch off and clean-up the machine & & & & & \\
\hline & Task 5 Score & & & & & \\
\hline
\end{tabular}

APPENDIX C: The competency-based affective skills on drilling and milling operations.

This test is designed to measure the student's ability in performing the affective skills in different tasks on drilling and milling operations.

The performance of each affective skill on any specific task should be demonstrated by each student and rated by the teacher to express the extent of their performance employing the five point Likert rating scale format with response options in the order of Very high for demonstration of any five (5) skills on the task, High for demonstration of any four (4) skills on the task, Moderately high for demonstration of any three (3) skills on the task, Low for demonstration of any two (2) skills on the task and Very Low for demonstration of any one (1) skill on the task. There will be no mark for none performance of any skill on the tasks.

Table 10: The competency-based affective required of metalwork students on Drilling operation

\begin{tabular}{|c|c|c|c|c|c|c|}
\hline \multirow[b]{2}{*}{$\mathbf{S} / \mathbf{N}$} & \multirow[b]{2}{*}{ Competencies relating to accident and its control } & \multicolumn{5}{|c|}{ Rating scales: } \\
\hline & & 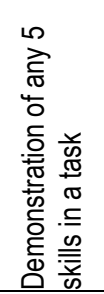 & 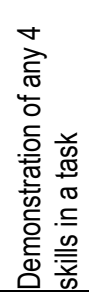 & 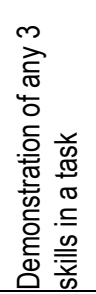 & 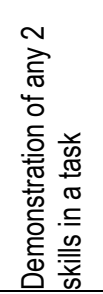 & 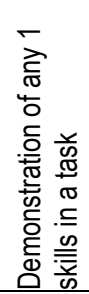 \\
\hline 1 & $\begin{array}{l}\text { Ability to abide by the human and environmental conditions } \\
\text { that may lead to accident during shaping operations }\end{array}$ & & & & & \\
\hline 2 & $\begin{array}{l}\text { Ability to comply with the safe working practices when } \\
\text { carrying operations on drilling machines }\end{array}$ & & & & & \\
\hline 3 & $\begin{array}{l}\text { Ability to observe safety rules and regulations associated } \\
\text { with protective clothing and equipment during drilling work } \\
\text { operations. }\end{array}$ & & & & & \\
\hline 4 & $\begin{array}{l}\text { Ability to be mindful of the dangers associated with the use } \\
\text { of drilling operation tools. }\end{array}$ & & & & & \\
\hline \multirow[t]{3}{*}{5} & $\begin{array}{l}\text { Ability to keep the work place from oily rags and pieces of } \\
\text { metals that may cause obstruction to other workshop users }\end{array}$ & & & & & \\
\hline & Score & & & & & \\
\hline & $\begin{array}{l}\text { Competencies relating to personal value and } \\
\text { relationship. }\end{array}$ & & & & & \\
\hline 6 & $\begin{array}{l}\text { Ability to exhibit positive attitude such as truthfulness and } \\
\text { politeness when dealing with people. }\end{array}$ & & & & & \\
\hline 7 & Ability to exhibit the spirit of respect for people & & & & & \\
\hline
\end{tabular}




\begin{tabular}{|c|c|c|c|c|c|c|}
\hline \multirow[b]{2}{*}{$\mathbf{S} / \mathbf{N}$} & \multirow[b]{2}{*}{ Competencies relating to accident and its control } & \multicolumn{5}{|c|}{ Rating scales: } \\
\hline & & 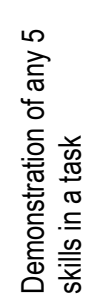 & 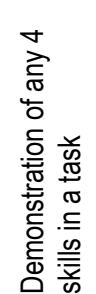 & 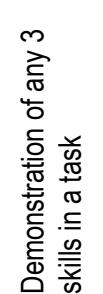 & 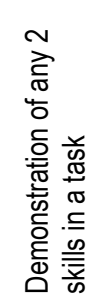 & 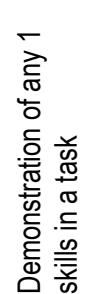 \\
\hline 8 & $\begin{array}{l}\text { Ability to demonstrate personal values such as cleanliness, } \\
\text { cheerfulness, smartness etc on drilling job. }\end{array}$ & & & & & \\
\hline 9 & $\begin{array}{l}\text { Ability to exhibit good work habits, such as cleaning the } \\
\text { work place and the tools accessories before and after } \\
\text { drilling works }\end{array}$ & & & & & \\
\hline \multirow[t]{3}{*}{10} & $\begin{array}{l}\text { Ability to follow the right steps to convince people on } \\
\text { drilling jobs. }\end{array}$ & & & & & \\
\hline & Score & & & & & \\
\hline & $\begin{array}{l}\text { Competencies relating to time management and } \\
\text { work ethics. }\end{array}$ & & & & & \\
\hline 11 & $\begin{array}{l}\text { Ability to exhibit sense of punctuality and regularity to work } \\
\text { place }\end{array}$ & & & & & \\
\hline 12 & $\begin{array}{l}\text { Ability to exhibit emotional intelligence necessary for } \\
\text { feeling beloved and accepting losses when they occur }\end{array}$ & & & & & \\
\hline 13 & $\begin{array}{l}\text { Ability to exhibit good work ethics, such as avoiding } \\
\text { wastages, giving tolerances, setting boundaries in order to } \\
\text { maintain personal integrity drilling jobs. }\end{array}$ & & & & & \\
\hline 14 & $\begin{array}{l}\text { Ability to exhibit good work ethics such as honesty in } \\
\text { prizing and the quality of material used for working. }\end{array}$ & & & & & \\
\hline 15 & $\begin{array}{l}\text { Ability to exhibit proper arrangement of tools, equipment } \\
\text { and materials in the rightful positions to avoid a mix of } \\
\text { items. }\end{array}$ & & & & & \\
\hline & Score & & & & & \\
\hline
\end{tabular}

Table 11: The competency-based attitude (affective) required of metalwork students on milling operation:

\begin{tabular}{|c|c|c|c|c|c|c|}
\hline \multirow[b]{2}{*}{$\mathbf{S} / \mathbf{N}$} & \multirow[b]{2}{*}{ Competencies relating to accident and its control } & \multicolumn{5}{|c|}{ Rating scales: } \\
\hline & & 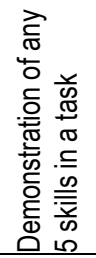 & 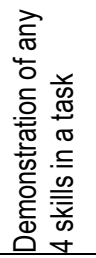 & 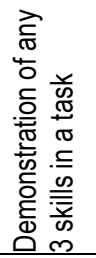 & 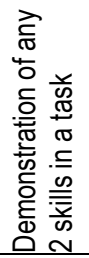 & 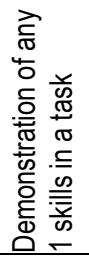 \\
\hline 1 & $\begin{array}{l}\text { Ability to abide by the human and environmental } \\
\text { conditions that may lead to accident during shaping } \\
\text { operations }\end{array}$ & & & & & \\
\hline 2 & $\begin{array}{l}\text { Ability to comply with the safe working practices when } \\
\text { carrying operations on lathe machines }\end{array}$ & & & & & \\
\hline 3 & $\begin{array}{l}\text { Ability to observe safety rules and regulations associated } \\
\text { with protective clothing and equipment during milling } \\
\text { operations. }\end{array}$ & & & & & \\
\hline 4 & $\begin{array}{l}\text { Ability to be mindful of the dangers associated with the } \\
\text { use of milling operation tools. }\end{array}$ & & & & & \\
\hline 5 & $\begin{array}{l}\text { Ability to keep the work place from oily rags and pieces of } \\
\text { metals that may cause obstruction to other workshop } \\
\text { users }\end{array}$ & & & & & \\
\hline & Score & & & & & \\
\hline
\end{tabular}




\begin{tabular}{|c|c|c|c|c|c|c|}
\hline \multirow[b]{2}{*}{$\mathbf{S} / \mathbf{N}$} & \multirow[b]{2}{*}{ Competencies relating to accident and its control } & \multicolumn{5}{|c|}{ Rating scales: } \\
\hline & & 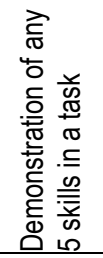 & 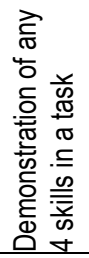 & 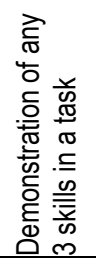 & 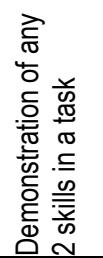 & 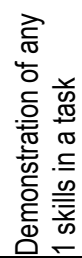 \\
\hline & $\begin{array}{l}\text { Competencies relating to personal value and } \\
\text { relationship. }\end{array}$ & & & & & \\
\hline 6 & $\begin{array}{l}\text { Ability to exhibit positive attitude such as truthfulness and } \\
\text { politeness when dealing with people. }\end{array}$ & & & & & \\
\hline 7 & Ability to exhibit the spirit of respect for people & & & & & \\
\hline 8 & $\begin{array}{l}\text { Ability to demonstrate personal values such as cleanliness, } \\
\text { cheerfulness, smartness etc on the milling job. }\end{array}$ & & & & & \\
\hline 9 & $\begin{array}{l}\text { Ability to exhibit good work habits, such as cleaning the } \\
\text { work place and the tools accessories before after work }\end{array}$ & & & & & \\
\hline \multirow[t]{3}{*}{10} & Ability to follow the right step to convince people. & & & & & \\
\hline & Score & & & & & \\
\hline & $\begin{array}{l}\text { Competencies relating to time management and } \\
\text { work ethics. }\end{array}$ & & & & & \\
\hline 11 & $\begin{array}{l}\text { Ability to exhibit sense of punctuality and regularity to } \\
\text { work place }\end{array}$ & & & & & \\
\hline 12 & $\begin{array}{l}\text { Ability to exhibit emotional intelligence necessary for } \\
\text { feeling beloved and accepting losses when they occur }\end{array}$ & & & & & \\
\hline 13 & $\begin{array}{l}\text { Ability to exhibit good work ethics, such as avoiding } \\
\text { wastages, giving tolerances, setting boundaries in order to } \\
\text { maintain personal integrity. }\end{array}$ & & & & & \\
\hline 14 & $\begin{array}{l}\text { Ability to exhibit good work ethics such as honesty in } \\
\text { prizing and the quality of material used for working. }\end{array}$ & & & & & \\
\hline \multirow[t]{2}{*}{15} & $\begin{array}{l}\text { Ability to exhibit proper arrangement of tools, equipment } \\
\text { and materials in the rightful positions to avoid a mix of } \\
\text { items. }\end{array}$ & & & & & \\
\hline & Score & & & & & \\
\hline
\end{tabular}

\section{Answers to the cognitive knowledge Questions:}

$\begin{array}{ll}\mathbf{1} & \text { B } \\ \mathbf{2} & \text { D } \\ \mathbf{3} & \text { B } \\ \mathbf{4} & \text { B } \\ \mathbf{5} & \text { B } \\ 6 & \text { C } \\ 7 & \text { B } \\ \mathbf{8} & \text { A } \\ 9 & \text { B } \\ 10 & \text { B } \\ 11 & \text { C }\end{array}$

